\title{
SESA Keynote Speaker and 25th Secretary of the United States Air Force, Barbara Barrett
}

\section{Melissa Layne}

\section{American Public University System}

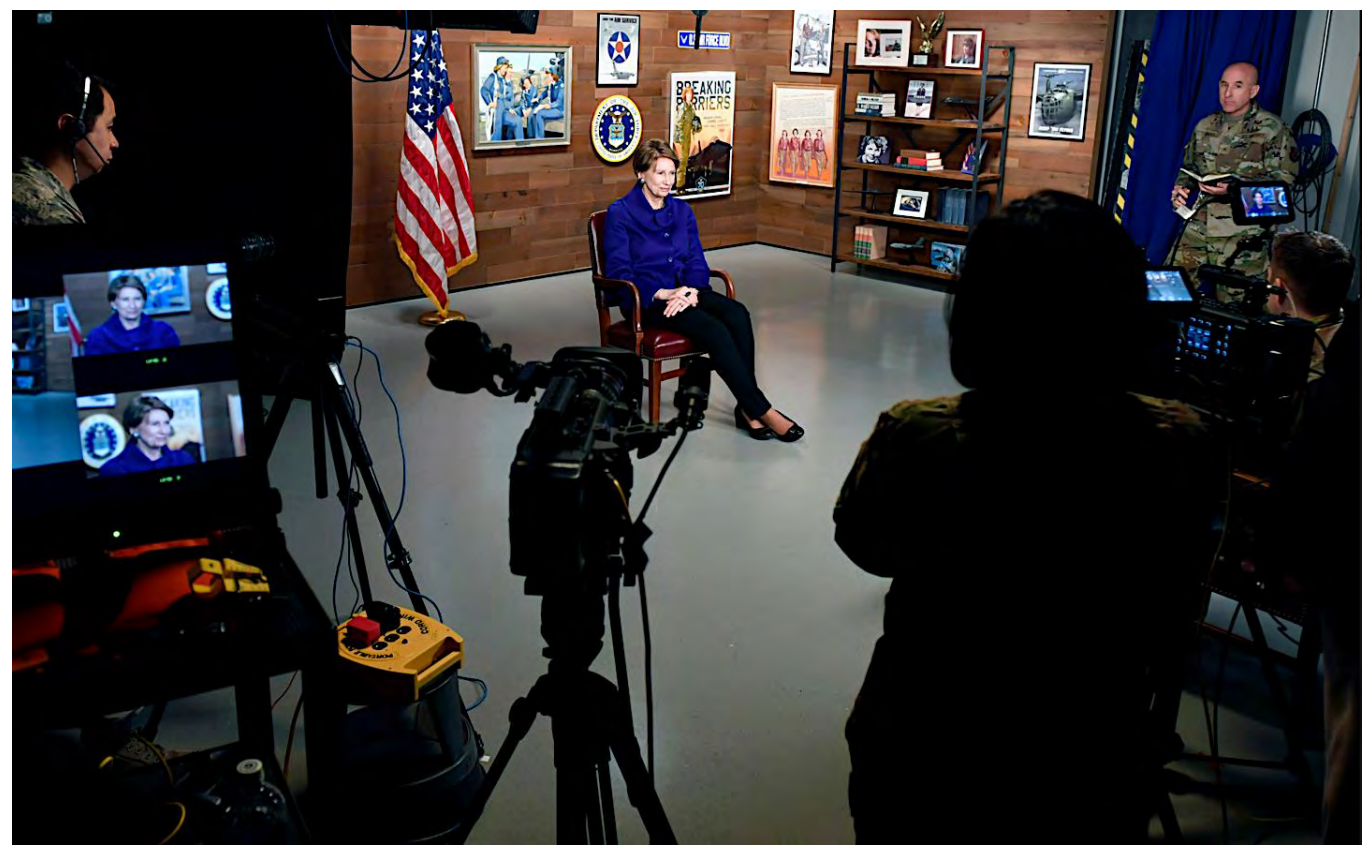

Figure 1. Secretary of the Air Force Barbara M. Barrett conducts her first Air Force TV interview with Airmen at the Pentagon, Arlington, VA on October 24, 2019. (U.S. Air Force photo by Wayne Clark)

\section{Abstract}

Despite Secretary Barrett's recent resignation (which preceded President Joe Biden's inauguration), the $25^{\text {th }}$ U.S. Air Force secretary (and fourth female secretary), was a much-anticipated keynote speaker at October's inaugural Space Education and Strategic Applications (SESA) conference. As a SESA conference organizer and editor-in-chief for the associated SESA journal, preparing for Mrs. Barrett's keynote was nothing short of surreal. I was tasked to organize the date, time, duration of the keynote, and to develop 5 interview questions (which, I readily admit, went through roughly 5 iterations). Prior to drafting the questions, I had the once-in-a-lifetime opportunity to communicate with and organize our virtual conference logistics with her Public Affairs Advisor and Director of Engagements ... from the Pentagon ... vis-à-vis emails and phone calls. 
Mr. Lou Cordia, Senior Advisor of Government Relations for American Public University System and friend to Barrett, was requested to introduce the Secretary, and present the interview questions. Presenters and attendees enjoyed listening to our esteemed guest who shared inspirational life experiences that helped shape her successful career with the U.S. Air Force. Needless to say, Barbara Barrett is quite a remarkable woman. Her biography documents her achievements, accolades, and appointments since 1976. In this article, I share the captivating stories behind the documents and interviews to unearth Barrett's views on the importance of work ethic, education, determination, and of course, space.

Keywords: Secretary Barbara Barrett U.S. Air Force, Space Education and Strategic Applications conference, journal, space, education, ethics, airmen, biography

\section{Oradora principal de SESA y $25^{\circ}$ Secretaria de la Fuerza Aérea de los Estados Unidos y Barbara Barrett}

\section{RESUMEN}

A pesar de la reciente renuncia del secretario Barrett (que precedió a la toma de posesión del presidente Joe Biden), la vigésimo quinta secretaria de la Fuerza Aérea de los Estados Unidos (y cuarta secretaria) fue una oradora principal muy esperada en la conferencia inaugural de Educación Espacial y Aplicaciones Estratégicas (SESA) de octubre. Como organizador de la conferencia de SESA y editor en jefe de la revista asociada de SESA, la preparación para el discurso de apertura de la Sra. Barrett fue nada menos que surrealista. Se me asignó la tarea de organizar la fecha, la hora, la duración de la conferencia magistral y desarrollar 5 preguntas para la entrevista (que, lo admito, pasaron por aproximadamente 5 iteraciones). Antes de redactar las preguntas, tuve la oportunidad única de comunicarme y organizar nuestra logística de conferencia virtual con su Asesora de Asuntos Públicos y Directora de Compromisos ... del Pentágono ... vis-à-vis correos electrónicos y llamadas telefónicas.

Se pidió al Sr. Lou Cordia, Asesor Principal de Relaciones Gubernamentales para el Sistema Universitario Público Estadounidense y amigo de Barrett, que presentara al Secretario y presentara las preguntas de la entrevista. Los presentadores y asistentes disfrutaron escuchando a nuestra estimada invitada, quien compartió 
experiencias de vida inspiradoras que ayudaron a dar forma a su exitosa carrera con la Fuerza Aérea de EE. UU. No hace falta decir que Barbara Barrett es una mujer bastante notable. Su biografía documenta sus logros, reconocimientos y nombramientos desde 1976. En este artículo, comparto las cautivadoras historias detrás de los documentos y entrevistas para desenterrar las opiniones de Barrett sobre la importancia de la ética laboral, la educación, la determinación y, por supuesto, el espacio.

Palabras clave: Secretaria Barbara Barrett, Fuerza Aérea de los EE. UU., Conferencia sobre educación espacial y aplicaciones estratégicas, revista, espacio, educación, ética, aviadores, biografía.

\section{SESA主题演讲者和美国空军第25秘书以及 Barbara Barrett}

\section{摘要}

尽管巴雷特秘书最近辞职（在乔 - 拜登总统就职之前），但 美国第25空军秘书（和第四位女秘书）还是在10月举行的首 届太空教育和战略应用（SESA）会议上备受期待的主旨发言 人。作为SESA会议的组织者和SESA相关杂志的主编, 为巴雷 特夫人的主题演讲做准备简直就是超现实。我的任务是组织 主题演讲的日期，时间，持续时间，并制定5个面试问题（ 我很容易承认，经历了大约5次迭代）。在草拟问题之前, 我有千载难逢的机会与五角大楼的公共事务顾问和参与总监

（来自五角大楼）进行交流并组织我们的虚拟会议后勤…… 面对电子邮件和电话。

美国公立大学系统政府关系高级顾问, 巴雷特的朋友楼- 科 迪亚 (Lou Cordia) 先生被要求介绍秘书, 并提出面试问 题。主持人和与会者很高兴听取我们尊敬的客人的声音, 他 们分享了鼓舞人心的生活经历, 这些经历有助于塑造她在美 国空军的成功事业。冊庸置疑, 芭芭拉 -巴瑞特（Barbara Barrett）是一位了不起的女人。她的传记记录了自1976年 以来她的成就, 荣誉和任命。在本文中, 我分享了文件和访 谈背后的迷人故事, 以发掘巴雷特对职业道德, 教育, 决心 以及空间的重要性的看法。

关键词: 秘书芭芭拉.巴雷特, Barbara Barrett, 美国空军, 太 空教育和战略应用会议, 期刊, 太空, 教育, 伦理学, 飞行 员，传记 


\section{Work Ethic \& Education}

CC

grew up on a farm. I ended up being the sole source of income. work to get the job done. You pursue until you accomplish the mission.

You know growing up we didn't have much money was always in short supply. I kept a tobacco can that was my bank. I put money in that bank. And if anybody asked me what that was for, [I would say] I was saving it to go to college. My life education was the ticket to capability or the ticket to opportunity. And so, I got a bachelor's degree and then I went to night school to get a master's degree. I had to work five jobs at a time to get through to pay for this, but I got the education and that has been the doorway to opportunity. I would certainly not be here today, if it weren't for the education that I had to scrimp for." (Barrett, 1999).

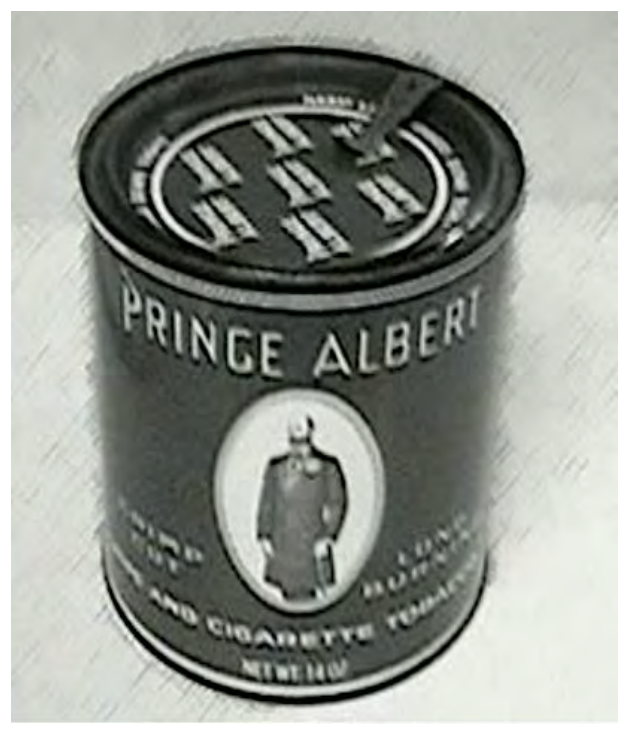

Figure 2. The tobacco can where Barbara Barrett saved her money to go to college.

\section{An Impressive Resume}

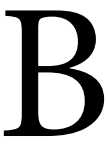

arrett's career started very early in life. One of Barrett's earlier resumes proudly displays her first job at McConnell's Riding Academy in Clarksburg, Pennsylvania. At the young age of 13 , she shoed and trained horses and also taught people how to ride. To evidence her determination and grit, on the resume she described her responsibilities at the academy as "Whatever it Took. Ran the whole enchilada." (Barrett, 1999).

Following high school, she landed a scholarship to Arizona State University where she would earn not only her Bachelor of Science in Liberal Arts, but a Master of Public Administration in international business, and a Juris Doctor degree. She remembers a time when she stretched her funds to insure she could continue to go to college:

"I recall that at one point I lived for two months on $\$ 2$ and I had five jobs to have to pay tuition and buy books." (Barrett, 1999)

\section{Professional Career}

or nearly five decades, Barrett
has held high-level positions in
business, academics, professional organizations-and of course, government. Before the age of 30 , she was an executive of two global Fortune 500 companies. However, one will notice a common thread throughout her career that places a distinct, and specialized focus on an industry that paved the way to her to her current position ... space. Space, aviation, aeronautics, science, 

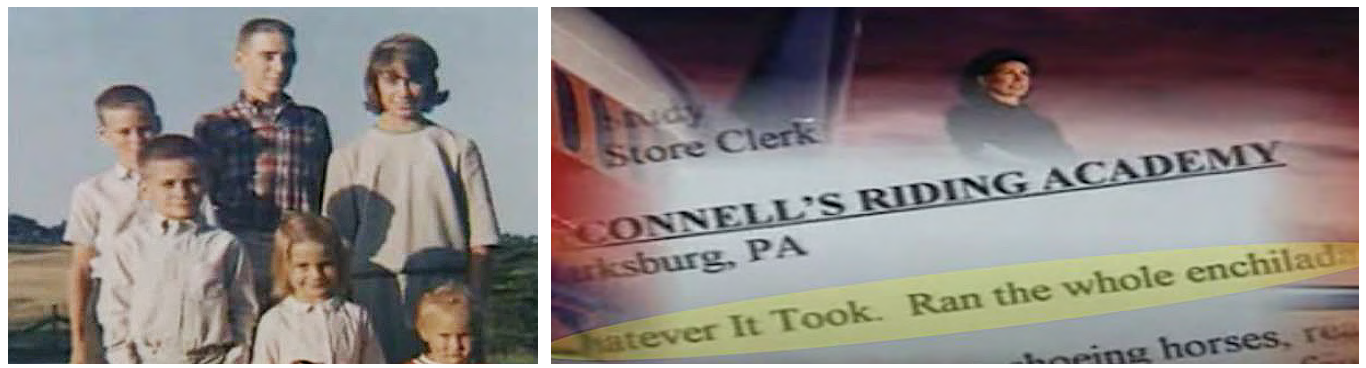

Figure 3. (L) Barbara Barrett as a young girl. Figure 4. (R) A description of Barrett's responsibilities at McConnell'S Riding Academy, "Whatever It Took. Ran the whole enchilada."

defense, and diplomacy she refers to as "home":

"Aviation is a big part of my life and space is, too. For me, the Air Force is a very comfortable home and a place that feels like the right fit," she says. She adds that her position as the Secretary of the U.S. Air Force is "an extraordinary privilege.” (Barrett, 2019).

\section{Supporting United States Airmen}

C6 also know that every Airman, when they raise their hand to defend the country and the Constitution, is making a bigger commitment than I am. My job will be to give them the tools, give them the resources, give them the support, and get out of the way."

During her tenure at the Pentagon, Barrett emphasized her allegiance to removing unnecessary regulations and modernizing operations toward the goal of making "faster and smarter decisions." (Barrett, 2019).

This efficiency contributes to a much larger purpose: the U.S. Space
Force. Even from conception, she had extremely high expectations for the U.S. Space Force as she firmly states,

"We have to be first and best in space for the world's safety and especially the defense of America .... A United States Space Force is not just a good idea; I might even say it's overdue .... It's really time for us to be attentive to our dependence on space, the urgency of space, the importance of space, and the need for us to continue our lead in the warfighting domain." (Barrett, 2019).

This need to "lead" is not merely to be the best. Barrett details our nation's vulnerability and dependence on space:

"We are vulnerable. For example, the U.S. and the global economy are totally dependent on satellites, most especially the GPS, which is operated by the Space Force. "It is a remarkable thing how completely dependent most Americans and people around the world are in our day-to-day lives on space. As I've said before, I think most people before their 


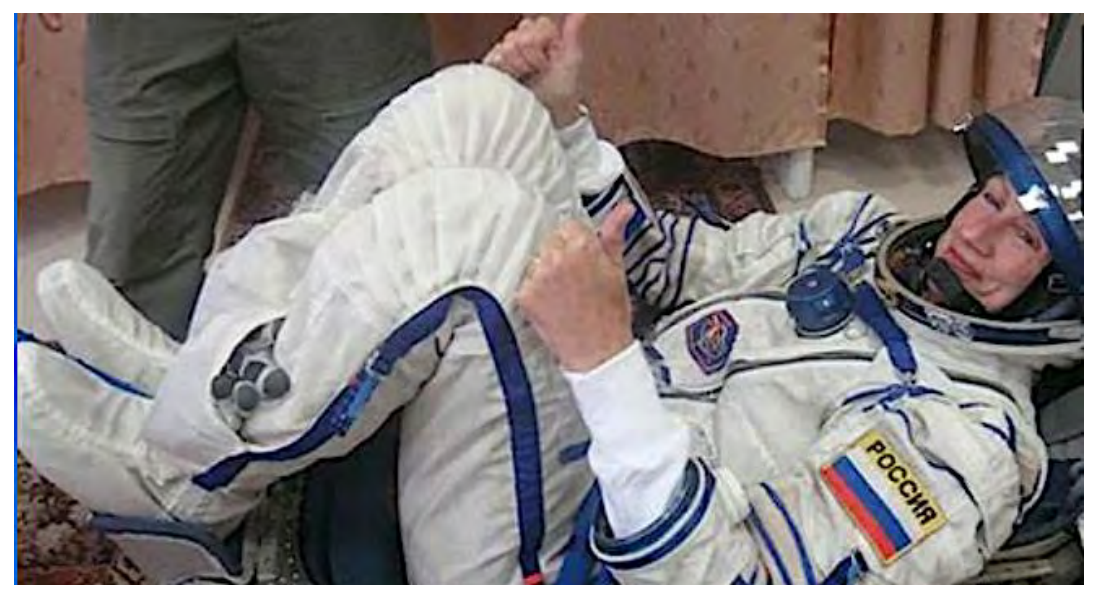

Figure 5. A fully-trained astronaut, Barrett was a "back-up" astronaut for the Soyuz TMA-16 flight to the International Space Station.

first cup of coffee in the morning, they've used space. It's ubiquitous, but it's invisible. So, most people don't realize it. I mean, you may wake into an alarm clock that is set to a timer that is airborne. That is space-born. It's coming from a satellite. Our ATMs. You can't pump gas without using space. The news probably is derived from a space asset. Our weather predictions are coming from space assets; crop monitoring, environmental monitoring, these things are all dependent upon space. Just in summary, our information, our navigation and our communications are all space-dependent. It's ubiquitous, but it's invisible. We don't see those lines to space. If they were all tethered by some wires, we'd be wrapped up in it like Lilliputian, like Jonathan Swift. But in fact, we are dependent, but not conscious in many cases of how dependent we are. So, with that dependence, we built this system, the GPS system especially-as my predecessor in this role said, we built a glass house before we knew about stones, in that we have a vulnerable system, but we built it without consciousness of that vulnerability. So now those satellites, that GPS system upon which we depend, has been unprotected. We need to be able to protect that capability, and we need to deter others from attacking our GPS satellites, and we need to replace the current satellites with less vulnerable, more jam-resistant and protected satellites." (Forbes, 2020).

\section{Bidding the USAF Farewell}

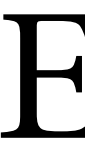

ven though her tenure with the Air Force has ended, Barrett took the opportunity to share some parting words during her farewell ceremony on January 14th at Joint Base Anacostia-Bolling in Washington, D.C. She commended the "superstars" she led and mentored by accentuating their 
ethics, integrity, and drive to be a collective "best" - the same characteristics she had as a little girl raising cattle and training horses on a 100-acre farm back in Pennsylvania:

"There is one eye-watering constant across the Air and Space Forces: the universality that these
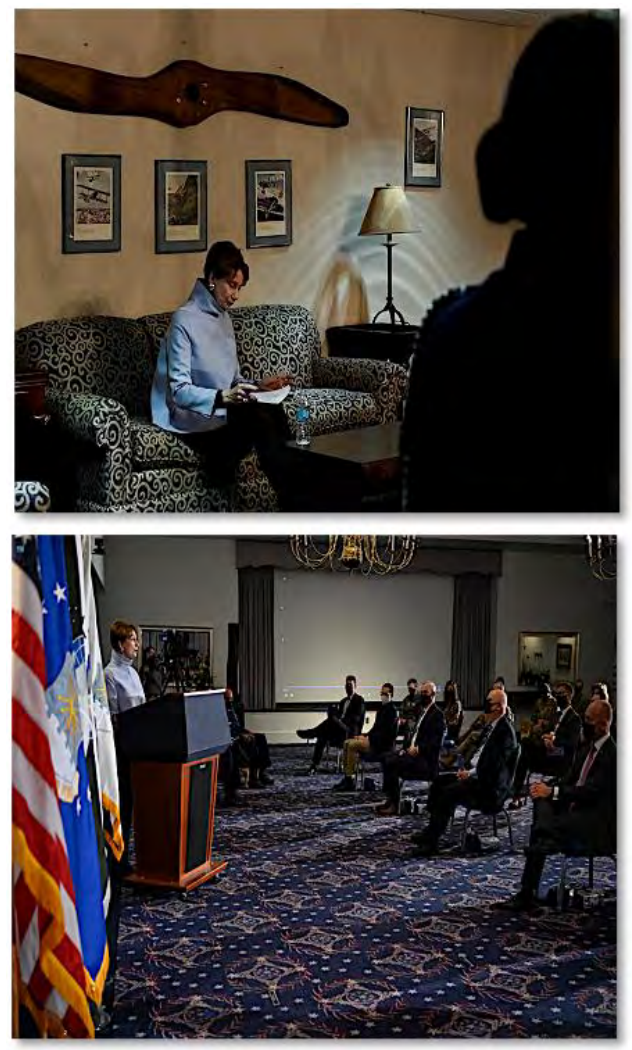

are good people," she said. "I have worked at numerous businesses, I have been a member of dozens of groups, and I have been part of myriad organizations, but I have never been part of any entity where there is such consistency of good intent and effort to be the best, together."
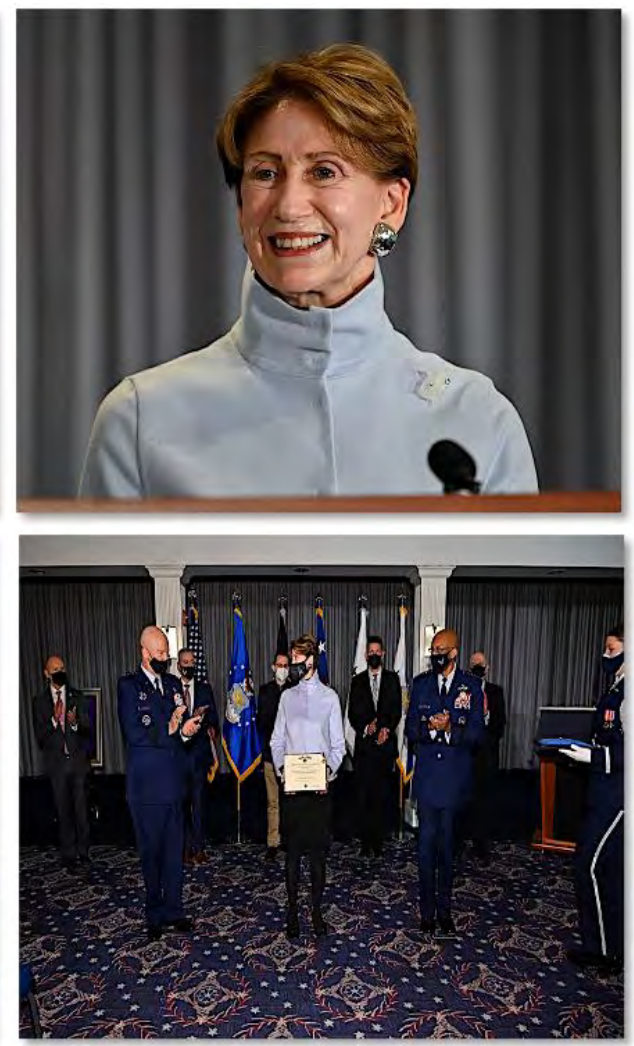

Figure 6. Secretary of the Air Force Barbara M. Barrett delivers remarks during her farewell ceremony at Joint Base Anacostia-Bolling, Washington, D.C., Jan. 14, 2021. As the 25th Secretary of the Air Force, Barrett was responsible for the welfare of more than 697,000 active duty, Guard, Reserve, and civilian Airmen and Guardians and their families. (U.S. Air Force photos by Eric Dietrich)

\section{Additional interesting facts about the 25th Secretary of the U.S. Air Force, Barbara Barrett:}

- She trained in her late 50s as an astronaut in Kazakhstan and then in Russia.

- She had to learn Russian while undergoing astronaut training. 
- She was the first civilian woman to land in an F-18 fighter aircraft on a moving aircraft carrier.

- She has successfully held executive positions in both the private and public sectors.

- She served as our ambassador to Finland, where she engaged in a war game dog fight in the air in an F-18 against the head of the Finnish Air Force (the joust was a draw).

- At age 10 learned how to drive a car, milk a cow, and shoe a horse.

- At age 13, she became her family's bread-winner after her father suffered a heart attack.

- Each year she writes a life-list, which has included activities such as climbing Kilimanjaro, and exploring the Grand Canyon from rim to rim.

- One of her five jobs while attending Arizona State University was a paid internship at the state legislature where she also received credit hours and worked with Sandra Day O'Conner, the first woman to sit on the majority leader of the state senate.

\section{References}

Forbes, Steve. "The Space Force: A Conversation With United States Secretary Of The Air Force Barbara Barrett." Steve Forbes: What's Ahead, Chairman and Editor-in-Chief Steve Forbes, Forbes Media, November 13, 2020, https://www.forbes. $\mathrm{com} /$ sites/steveforbes/2020/11/13/the-space-force-a-conversation-with-unitedstates-secretary-of-the-air-force-barbara-barrett/?sh=152c6e1841fa

Horatio Alger Association. "Barbara Barrett - 1999 Horatio Alger Award Winner." YouTube, Horatio Alger Association, September 17, 2008, https://www.youtube. $\mathrm{com} /$ watch? $=$ BlXE9pBTd 80

Secretary of the Air Force Public Affairs. "An introduction - Secretary of the U.S. Air Force, Barbara Barrett." Edwards Air Force Base, Air Force Public Affairs, November 21, 2019, https://www.edwards.af.mil/News/Article/2022797/an-introduc tion-secretary-of-the-air-force-barbara-m-barrett/

Secretary of the Air Force Public Affairs. "SecAF discusses early influences." Hanscom Air Force Base, Secretary of the Air Force Public Affairs, November 21, 2019, https://www.hanscom.af.mil/News/Article-Display/Article/2023766/sec af-discusses-early-influences/ 